\title{
Dropping out/dropping back in: Matters that make learning matter
}

\author{
Anna Lund and Mats Trondman \\ anna.lund@Inu.se, mats.trondman@Inu.se
}

\begin{abstract}
Nearly one in three students living in the segregated, multicultural city of Malmö, Sweden, fails to finish school with a completed diploma. To remedy this situation, students can attend introductory programs, but only some students who do so end up with a diploma. The aim of this article is to understand why young people from a migration background drop out of secondary school and why some of them drop back in and become school achievers. We explore what makes learning matter among youth who drop back into schooling. In seeking possible answers to this question, we listened to and learned from the students themselves. We hope readers will learn about the elementary forms of an enabling opportunity structure for school achievement, about the significance of relational capital, and about the deeply associated meanings of family and friendship and their importance to school success. The article is framed by the interdependencies of two conditioned temporalities: the temporality of the past - that is, the dropping-out process - and the temporality of the present, that is, the dropping-back-in process. We argue that school failure is not an inevitable phenomenon, and show that young people who are supported to drop back into schooling can discover that they are capable of learning with passion and perseverance.
\end{abstract}

\section{Introduction}

The over-arching aim of this article is not only to try to understand why young people who have a migration background and live under adverse circumstances may drop out of secondary school in Malmö City, Sweden, but also why they may drop back in, and do so with passion and perseverance. ${ }^{1}$ Here the term 'dropping out' refers to processes by which students end up not meeting the requirements of a secondary school degree by not coming to school, or coming to school but not always turning up in classrooms, or not engaging in ongoing teaching and learning. Accordingly, the term 'dropping back in' concerns processes that work in the reverse direction in which former dropouts ${ }^{2}$ return to school and become engaged in ongoing teaching and learning to fulfil the requirements of a secondary school diploma. Nonetheless, the point we wish to make here is that the dropping back in process should not be conceived of as merely coming to school: it is also 
a matter of being mobilised to cooperate, willingly or even eagerly, with a school that provides an opportunity structure ${ }^{3}$ for school achievement. ${ }^{4}$

\section{Dropping out and back into schooling}

From our analytical viewpoint, the two processes of dropping out and dropping back in concern disapproving of and approving of, respectively, what education in a school is inevitably about - namely schooling. Political theorist Michael Oakeshott (2001: 62) writes: 'Education in its most general significance may be recognized as a specific transaction that may go on between the generations of human beings in which newcomers to the scene are initiated in to the world they are to inhabit.' Thus understood, education becomes schooling when this transaction happens in the educational institution we call school, which is a particular place 'deliberatively designed for and devoted to learning' (2001: 10). Schooling, then, occurs 'when learning becomes learning by study, and not by chance, in conditions of direction and restraints' (2001: 69). As such, schooling concerns serious and ordered initiations into matters that are intellectual, imaginative, moral, sensory and emotional. Therefore, as educationalist David Cohen (2011) asserts, for teaching to become learning, the students themselves have to agree upon it. The same, of course, applies to teachers. They too have to embark upon schooling by being there as professionals in the lived midst of it all. They need, as Cohen puts it, to 'know how to do with students' while students, in turn, need to 'know how to do themselves, with one another, with some content, and with their teachers in their environment' (2011: 51).

\section{Lived experiences and frames of meaning}

Here we will examine and learn from young people's own lived experiences ${ }^{5}$ of dropping out of and back into schooling. There is thus a great deal to be gained from comparing their understanding of the adversity of the past with their understanding of the prosperity of the present. In tuning into such narrated comprehension of these two processes, we are informed by anthropologist Clifford Geertz, who once stated that to get to know other people, it is 'necessary to gain a working familiarity with the frames of meaning within which they enact their lives' (1999: 11). This 'involves discovering who' the people being studied 'think they are, what they think they are doing, and to what end they think they are doing it' (1999: 11; Trondman 2011). By seeking out the answers to these questions, we can gain the needed working familiarity with the changing frames of meaning within which these dropouts become students who drop back in.

\section{Guiding question and moves}

Our guiding question is, 'What are the matters that make learning matter?' in other words, the circumstances that can turn failed schooling into successful schooling. Our pursuit of answers to this question will involve proceeding through four affiliated moves in our argument. The scene where we are going to meet the participating students is a special school for secondary school dropouts in Malmö City, Sweden, which we call Vista High. We thus need to give the reader a picture of the educational context in which our study is set. Against the backdrop of this 
first move, we then present the method and the design of our case study. Aptly, our third move involves empirical descriptions and theorising of the two processes of dropping out and dropping back in. Our final move entails a more synthesised theorisation of matters that make learning matter, which at its core concerns a form of learning in which students who drop back into schooling learn that they are capable of learning (Trondman 2016b).

\section{The educational context}

In Sweden, children start school in the autumn of the year they turn seven. After nine years of compulsory schooling, they are expected to graduate and enter a three-year-long upper secondary school program. Attending such a program is not compulsory; nevertheless, a very large majority of young people continue to upper secondary education, which is free. In 2011, when most of the young people in this study were to have entered upper secondary school, nine out of ten young people in their age group did so, choosing either a college preparatory or vocational program. The former choice is more common than the latter (NAE 2014a).

\section{Introductory programs and their students}

Not all students leaving secondary school meet the requirements to enter upper secondary school. Instead, they are offered a third track called introductory programs, which most secondary school dropouts enter. The main objective of these programs is to support young people who have disengaged from education to drop back into schooling, with the ultimate goal being attainment of an upper secondary school degree (NAE 2014a). Earning this degree is of great importance because it is a strong indicator of a better future when it comes to jobs, income and wellbeing (Norberg 2003).

Boys make up a slighter larger proportion of the students entering introductory programs. These students largely come from low-income families with low educational capital. Having a migrant background is also common, and it generally means that the parents do not have sufficient mastery of the Swedish language to support their children's schoolwork. In addition, the average experience of earlier schooling is predominantly negative fuelled by inadequate learning support, poor relationships and low feelings of belonging. Lack of educational resources outside school is thus reinforced by a school environment that is unable to provide a working opportunity structure for these students. Hence these youth lag behind in terms of basic knowledge and learning skills. They also tend to end up having low self-reliance with regard to learning (Cederberg 2012; NAE 2014a). ${ }^{6}$

\section{Increase of dropouts and outcomes of introductory programs}

The proportion of Ninth Graders who fail to meet the requirements of a secondary school degree in Sweden has gradually increased over time, from about 5 per cent in the late 1990s to 14 per cent in 2014 (NAE 2008, 2014b). This increase is often ascribed to several profound and interrelated contextual changes in Swedish society. These include the increased divide in socio-economic resources between the haves and have-nots, increased segregation between the neighbourhoods in which 
young people grow up, and a decrease in equivalence of opportunity structures provided by different schools (Ambrose 2016; Bunar 2001, 2009; Bunar and Sernhede 2013). Accordingly, while the conditions of life outside schools are becoming more unequal, so are the conditions between schools, and this makes more resourceful parents and children prone to avoiding schools with bad results and reputations (Bunar 2009; Kallstenius 2010; Lundahl et al. 2014). In addition, since 2011 the formal requirements for entering upper secondary school have increased. ${ }^{7}$

The outcome of the introductory programs show us that within a two-year period, nearly one-third of introductory track students receive their secondary school diploma, and hence are qualified to enter upper secondary school, most often the vocational programs (NAE 2014a). A national report from the Swedish Association of Local Authorities and Regions shows that only 20 per cent of the students who started an introductory program (or, rather, an individual program as it was then called) in the fall of 2008 had met the requirements for a upper secondary school degree five years later (see Cederberg 2012: 22). So, even if nine in ten secondary school dropouts start introductory programs, we also know that a majority of them do not drop back into serious schooling — that is, they may go to school but they are not motivated to become school achievers.

\section{Dropping out in Malmö City}

National data shows that one in three students leave compulsory school in Malmö City without a completed diploma and then attend introductory programs (Cederberg 2012; NAE 2014a). This rate is markedly higher than the national average. The data also show a continuous increase in the proportion of youths who are dropping out in Malmö. Thus it is important to know more about shifting involvements in schooling. For the most part, these youth have grown up and lived in the four most markedly vulnerable neighbourhoods in Malmö City - that is, the areas most characterised by migration, segregation, low socio-economic status, low educational capital, unemployment, receipt of social welfare and restricted living space. These neighbourhoods are also the targets of highly negative public representations, and even racism, and based on their own lived experiences, the inhabitants are very well aware of, and have to deal with, this negativity (Trondman 2011; Trondman et al. 2014).

Regarding the conditions inside schools, most of the disengaged youth come from schools where the largest groups of students do not qualify for a secondary school diploma. In the face of all this, a lack of motivation for schooling has emerged, which in the end causes them to drop out of schooling (Cederberg 2012). Nevertheless, in this story we can also see an intriguing puzzle: students who have dropped out, as we will show, are also capable of dropping back into schooling with passion and perseverance. For very good reasons, we wish to identify matters that make learning matter to former dropouts who have dropped back into schooling in a context as highly divided as Malmö City.

\section{Method and design}

In this article, we have used empirical data from an ethnographic case study, ${ }^{8}$ including semi-structured interviews (with students, teachers, head teachers and other staff members) that Lund conducted at an introductory program at Vista High. ${ }^{9}$ 
For two academic years, she focused mainly on two groups of a total of 17 students who had successfully dropped back into schooling. The aim of the case study, drawing on the work of Geertz, was to gain a working familiarity with the changing frames of meaning within which the students enacted their new life of schooling at Vista High. Here we will encounter only seven students: Nazira, Ibra, Marsela, Ziad, Salma, Ada and Bahar (our pseudonyms for these students). Each of these young people has had an experience of migration, ${ }^{10}$ and is an illuminating examples of a dropout who, despite all the constraining circumstances described above, is dropping back into schooling. They are all true-life examples par excellence of the intriguing puzzle mentioned above. In this article, we will utilise Lund's (2015a, $2015 \mathrm{~b}, 2016$ ) interviews with this group of young people because our goal is to learn from and theorise each student's own lived experiences and comprehension of their shifting involvement with schooling. The account of parents' voices presented in this paper comes directly from Lund's conversations with their daughters and sons.

In our attempt to understand matters that make learning matter for former dropouts, we will focus on two temporalities. The first is the temporality of the past - that is, the dropping-out process; the second is the temporality of the present - that is, the dropping back in process. By moving from the first to the second temporality and back again, we will alternate between matters of adversity that cause learning not to matter and matters of prosperity that cause learning to matter more and more. In doing so, we can observe and learn from the interdependencies of these two conditioned temporalities - as if our study of actual former dropouts from Vista High were a detective story in reverse. While our study moves forward in its inquiry, it also needs to look back to reconstruct the meanings of the contexts, events and experiences that led not only to the dropping out process, but also the dropping back in process awakening students' beliefs in and the practice of schooling.

When we began empirically exploring these two interrelated temporalities, we discovered a recurrent pattern in the way the students gave voice to their experiences of dropping out and dropping back in. Looking back at their discussions of these processes in the interviews, the students talked a great deal about their family lives, their circle of friends and school. We therefore decided to frame our empirical descriptions and theorisation around these three interdependent areas of investigation, which we call the spheres of family, friendship and schooling. ${ }^{11} \mathrm{By}$ analytically exploring the changing content and relationships between these spheres and temporalities, we make a significant empirical and theoretical contribution to better understanding what makes learning matter among young people who drop back into schooling.

\section{The temporality of the past: Opening the gaps}

We will begin by exploring the three spheres of the first temporality, in which the students looked back to their past dropping out process.

\section{Family}

For the parents of Nazira, Ibra, Marsela, Ziad, Salma, Ada and Bahar, education was of great importance. More than anything else, education was understood as a means to ensure better opportunities in life in the new country. At first, the children shared their parents' hopes and dreams with high expectations about performing 
well in school and hopes to become people of high standing, such as doctors, lawyers and engineers. ${ }^{12}$ But their parents lacked the educational capital and Swedish language skills needed to support their children's schoolwork. They also lacked insight into the Swedish school system and the pragmatics of schooling. The parents, then, had to put their trust in the school representatives - primarily the teachers - and rely on what their children said about their own school performance. The dropping out process was thus very tense and emotionally charged, both for the parents and for the children. Nazira's mother was very disappointed: 'If you have the chance to get an education, why don't you take it?' she said, comparing the 'good opportunities here in Sweden' with 'the difficulties in our home country'. 'And then,' Nazira says, 'I'm just throwing it away.'

Ibra's mother was disheartened when she understood that her son was failing school. 'How can you not like school?' she asked him. Of course Ibra knew this was all about his mother's deep concern for his 'future'. 'But I was young and dumb,' he said. Indeed, he heard his mother repeatedly saying things like, 'You can be this and you can be that', meaning a 'lawyer' or a 'doctor', and 'You can be smart', but he could not 'take it in'.

Marsela recalled her mother's deep anger when she discovered that her daughter was not taking school seriously: 'You have chosen a completely wrong way in life,' she said. This standpoint needs to be seen in light of the fact that her mother had not been able to continue her own education due to the war in the former Yugoslavia. Moreover, Marsela's mother carried with her deeply hurtful experiences of living with a controlling and violent husband, Marsela's father. For Marsela's mother, education was the road not only to a good working life and wellbeing, but also to independence as a woman.

When the students in our study were dropping out and unable to meet their parents' expectations regarding education, this hit them hard and caused emotional pain. The easy way out of this situation was to simply not let their parents know. Salma made her mother believe she was doing well at school. She even tried to keep up appearances during a performance review involving herself, her mother and the class teacher. Because her mother did not understand Swedish very well and the teacher had not engaged a professional interpreter, Salma was expected to translate Swedish into Arabic. She did this, but to her own advantage. At first this approach seemed to work. But after a while her teacher understood that something was wrong. Why was Salma's mother smiling happily when the teacher was informing her about her daughter's school failures and truancy? Salma was not alone in such failed attempts at trickery.

From a theoretical perspective, this situation created a performance gap between what the parents believed in, hoped for and wanted, and what their children were actually achieving. This resulted in their children becoming existential carriers of the tensions and contradictions that characterise a performance gap in its lived forms. On the one hand, the students wanted to make their parents proud and to improve their opportunities in life. On the other hand, because they were not delivering such an outcome, they knew they were letting both their parents and themselves down. ${ }^{13}$ Thus weighty emotions such as frustration, anger and shame took hold of their thoughts and actions. The logic of deception, then, was a handy temporary solution used to keep their parents thinking everything was going well. 


\section{Friendship}

During Ada's days in secondary school, hanging out with friends came to frame her everyday life. Her days were filled with great laughs, shared cigarettes and energy drinks. Passing classes was not on the agenda. However, as Ada put it, 'directly after school I went home and I said to my mom: "School was good today."' And, she added cheekily, 'It was great because I wasn't there! I didn't care about school. I just cared about my friends.'

'I played truant and I didn't want to learn', Nazira stated. 'I was walking along the path of bad friends and they didn't want to learn either.' So they 'encouraged' me "to let go of any thoughts about school. "You won't learn anything, anyway," they exclaimed.' This kind of friendship in the face of adversity was considered a better option than embarking upon schooling. Looking back, Nazira said:

For me, it was more fun hanging out with my friends. Since with them I could at least understand what I was up to. Instead of sitting in on a lesson without a clue about what was going on, what I was supposed to do, or supposed to understand.

Salma left a private Muslim school that she and her parents found too strict for instance, because it had a dress code for female students. She was moved to a comprehensive secondary school where she immediately identified herself with and fell into a small informal group of unruly teenager girls with migration experiences. She did this because she thought they represented 'real grown-up things', which meant they wore make-up, smoked and did not like school. 'At that time in my life,' Salma said, 'I really wanted to be like them.' Looking back at this dropping out process, she recalled that school was nothing but a playground. She woke up around 12, went to school around lunchtime and met up with her friends. For Salma, school was just the meeting place: 'We always went to the city centre ... [and] we hung out, smoked and harassed other people.'

Because she was involved in these activities, Salma became what was at that time commonly known as a real 'GB', an acronym for being a 'gangster bitch' [gangsterbrud], which refers to a disorderly and dangerous 'immigrant girl' from a segregated neighbourhood of ill repute. 'If a girl looked suspiciously at me, I approached her directly,' Salma explained. Thus being a GB meant having a reputation for being outrageous and dangerous. Violence, both symbolic and physical, was a common experience among the interviewed students.

Friendship revealed a performance gap of its own - a gap situated between what the students believed in, hoped for and wanted in relation to what friendship ought to mean and what they actually ended up with in real life. In other words, this structure of feeling, which they understood at the time to be 'true' comradeship and belonging, seemed to make up for family gaps and school failure. ${ }^{14}$ Accordingly, the students who dropped out also become existential carriers, caught in the middle of the possibilities and constraints of friendship. What they really believed in friends who cared about each other's autonomy, wellbeing and future chances in life - was not, at least in hindsight, what they got. In this way, it is the logic of interlocking friendship that reigns - that is, feeling somewhat comfortable with people who effectively control one's disapproval of schooling. 


\section{Schooling}

As mentioned, all seven students dropped out during their secondary school days. What, then, is their understanding of why this happened? How did they see things in hindsight, when looking back at lived experiences from their current perspective as students who were dropping back into schooling at Vista High? Based on the stories told by Nazira, Marsela and Ziad, we will describe some variations on the most frequent reasons for dropping out - reasons that reverberated throughout the lived stories from which we have learned so much.

Nazira once 'loved school', but then came to 'hate school'. Listening to her descriptions of her shifting involvement, three interwoven explanations come through. First, she did not receive the learning support she both needed and wanted. At this time, despite her struggle to get help, she did not disapprove of schooling. Nonetheless, she said, 'the teachers had no time to help all of us that needed help'. Clearly, she saw that she was not alone in her struggles. Second, Nazira's narrative reveal that no deliberative acts of communication occurred between Nazira and her teachers. Thus it seems that no responsible adult at school took seriously what Nazira, and several others, thought, felt and wanted. The substance of what she really needed was neither jointly known nor professionally dealt with. Nazira's schooling became less and less a possibility and more and more an insurmountable obstacle. 'I grew tired of the situation,' she says, and when the support she needed was not provided, she gave up and 'left the classroom'. Finally, there was no sense of belonging at school. 'And so,' she concluded, 'you start hanging out with the wrong people' because they can create their own sense of belonging away from the lost opportunities of schooling. This shift also situated the students outside the realm of their parents' beliefs, hopes and desires, making the young people unable to repair relationships with significant others such as parents, friends and school professionals - at least for the time being.

When Marsela came to Sweden from Kosovo at age twelve, she had passing grades in all school subjects. But at her new school she was immediately targeted as an 'Albanian' and a newly arrived immigrant - someone who could not properly pronounce, use and understand Swedish. Her explanation was that the students who did this to her also had migration backgrounds, but from other countries; they 'thought they were higher and better than us' newly arrived immigrants. These experiences were devastating to Marsela, who could not cope with the situation by herself. And there was no support from the school. Adults at school either did not see, or saw but did not care, which was at least as hurtful as the racist bullying perpetrated by Marsela's peers. These experiences also came to limit her ability to focus on schooling. To escape this complete lack of recognition and relational support, and all her suffering, she increasingly avoided going to school. 'I was very tired,' she said, looking back, and added, 'The only thing I wanted to do was to sleep.' In the mornings, she told her mother she was going to school, but instead she went immediately to a friend's place to sleep through most of the day.

For Ziad, his experience with adults at school was similarly negative. 'The teachers did not know how to act towards me,' Ziad stated. 'If I didn't want to do anything, they just told me to leave the classroom.' They had no desire to know who he was, what he felt, wanted and needed. No attempts were made to achieve a meeting of minds. However, his lack of trust in secondary school teaching and 
learning had deep roots. An early experience of racism and lack of support from teachers had left deep, existential scars. 'Go back to your own country,' a pupil with a Swedish background had told him. 'So I just looked at him,' Ziad said, 'and then hit him, badly.' When teachers came to the scene, Ziad tried to explain to them what had happened. But they did not show any interest in listening to what he had to say. 'Nobody helped me,' he explained. Instead they framed him as a 'violent person' who was 'harming other people'. He could still remember the main response of one of the teachers handling the clash: 'It is more violent to fight than to use words.' He was nine years old, and that was a real blow to his belief in school, relations to others and self-understanding. He did not think violence was a legitimate response, but how could it be okay to make racist statements - to tell him he did not belong in his school and his new country? How could it be okay to be an adult school representative and only blame him? For Ziad, this became a lesson that he would never forget. School, he felt, could not be trusted. The conflicts between him and the teachers only escalated and hardened into given demarcation lines and trench warfare. Ziad did get a bad reputation, and unfortunately he often acted it out in practice. He became a sad case of a self-fulfilling prophecy (Merton 1996b). He played out for other people what they thought he was and expected him to be, and he turned out to be the school's biggest troublemaker.

These were the stories heard: no learning support, no attempts at reciprocal understanding and no sense of belonging. Matters that make learning in school matter were absent, which came to be deeply harmful in many ways. A third performance gap, then, is situated between what the students believed in, hoped for and wanted to happen in schooling and what they experienced in terms of lack of support for learning, deliberative communication and belonging. Consequently, the students became existential carriers of this lived gap because they were not getting what they expected to get and because they became what they were not supposed to become: lived examples of 'failures'. And just as the students eventually came to believe that the logic of deceiving parents and the logic of interlocking friendship might make the problem go away, at least for now, the logic of school failure, seen from the perspective of negative public representations, was also too easily interpreted in harmful ways by the students: as a source of 'insights' about 'those immigrant students' who cannot be saved, who cannot be reached and do not belong, because they lack motivation, learning and communication skills, as well as a willingness to belong. 'You stop trying,' Nazira stated, summing up the whole dropping out process, 'since it's like "it's all shit anyway", since I'm not going to make it, anyhow. And then, you don't make it because you have started thinking in that direction.'

\section{Gaps, logics, and shifting involvements}

We have learned that the lived possibilities of schooling are sometimes abandoned entirely, and that the price to pay for this abandonment is high. Looking back from the perspective of an ongoing dropping back in process opens up new horizons of understanding. Thus, although Nazira, Marsela, Ziad, Ibra, Salma, Ada and Bahar seemed to have learned that they could not make learning work at school, the reason for this attitude might not be that they were incapable of learning, but rather that they, as Nazira so cleverly put it, 'started thinking in that direction'. Thus, in 
the existentially lived midst of the deeply interwoven gaps of family, friendship and schooling, they became caught up in the logics of deception, interlocking friendship and what seemed to be personal school failure. This indicates that it is time for education researchers to start thinking in another direction and looking for matters that make learning matter.

\section{The temporality of the present: Closing the gaps}

Let us revisit the three spheres of family, friendship and schooling in the second temporality. At this point, things have changed for the students, involvements are shifting and the gaps between the three spheres are closing.

\section{Family}

The students are now very happy and proud of their new lives, because all of them are dropping back into schooling. Step by step, they are fulfilling the objectives that will earn them passing grades. ${ }^{15}$

'I hadn't opened a schoolbook in many years,' Ziad says, but now he does, and he cooperates with his teachers. Ziad is dropping back into schooling, and he has started becoming an achiever, which makes him 'happy'. 'I have also become happy,' he continues, 'since my parents care.' Every day, his father asks him about how school has been and what his results are. He asks because he knows what the answer will be. 'I'm proud of myself now,' Ziad adds. And his parents are, of course, also proud of him.

Ibra too is dropping back in, which has changed his relationship with his mother. He says: 'I've come much closer to her. Before we argued a lot; now we don't. Everything just calmed down. My family is my life. When I see that my mother is happy, I want to make her even happier.' When his performance review was coming up, Emma, Ibra's Swedish teacher, asked him how he felt about it. 'I've not felt this good since kindergarten,' he said. On his way home from school, he just wants to go back again. Nevertheless, it is also nice to come home in the role of the successful son.

Bahar remembers her mother's reaction during their first performance review at Vista High: 'Mom was just silent, and only nodded. She was shocked. She didn't think that I could improve [my school results] so much.' Thinking about it, Bahar recalls how things used to be not so long ago. 'My daughter, my daughter, my daughter,' her mother used to say on their way home from the review. 'All the time she talked about how I had to pull myself together.' Now Bahar happily jumps out of bed every morning, because she wants to go to school to learn and catch up.

All the students whom Lund has interviewed tell the same story. Salma's mother is also 'happy' and 'smiling'. There is no need for deception any longer. The same is true of Ada and Nazira, and their parents. Marsela's mother now expresses her deep appreciation of the teachers at Vista High, saying, 'I swear she loves them at lot.' Moreover, they will help their parents support their brothers and sisters. 'Don't make the same mistakes that I have made,' Ibra tells his brother, and so far his brother is doing well in school.

Thus the performance gap concerning the family is closing, which also means that the children are existential carriers of those beliefs, hopes and desires that 
everyone in the family shares. There is then a strong logic of repair going on, and it concerns not only dropping back into schooling and school achievement, but also mobilising family resources, wellbeing and a strong sense of belonging. This also brings back trust in the families' belief in education and school as a societal institution. In this way, dropping back into schooling is indeed a shifting of involvements.

\section{Friendship}

Not only does a closing family gap contribute to matters that make learning matter; friendship does as well - at least when it develops as it does at Vista High. Here are some illuminating examples of how the meaning of friendship in the past is redescribed in the light of the present, and of how the meaning of friendship in the present contributes to the process of dropping back into schooling.

Looking back, Salma finds that her friends in secondary school 'were actually not my friends'. Nevertheless, as she puts it, 'then I saw them as my friends'. And thinking about what she did to others back then during the dropping out process makes her feel deeply ashamed. It also makes her aware of what so-called friends can make you do under certain circumstances: 'My God, what kind of girl goes around beating up other girls?' she says. 'On the other hand, I was not alone, and it was not me at all. It was not who I am.'

'In the past,' Ziad says, 'I received respect through friends, but it's only bullshit it's actually no respect at all.' This is how he explains his shifting involvements with so-called friends: 'You come to understand that all that you have done before is wrong, you know; when you're mature, you'll choose the right type of friends and the right path.'

'It was stupid of me to listen to them,' Nazira says, looking back at the friends she had during her period of dropping out of schooling. Just like Ibra, Marsela, Ziad, Salma, Ada and Bahar, she can see this now, after having developed new and much more socially productive friendships in and outside Vista High. Having supportive friends during the dropping back in process meant being part of a circle of friends who help each other out in the name of schooling (see also Trondman et al. 2012). This is indeed a fragile process, one without a given outcome that takes into account the students' earlier experiences of failure in a variety of contexts. Bahar, for instance, works hard to motivate her friends to go to school and focus on schoolwork; she also supports friends who are still in the dropout mode. 'You can do it,' she explains to them. 'You have to start to build your life now and the only choice you have is to start here [at Vista High].' Indeed, Bahar, Nazira, Ibra, Marsela, Ziad, Salma and Ada have become ambassadors for schooling in general, and Vista High in particular. Trusting in friends who are positive about school is of great significance if one is to cooperate with teachers, work towards self-reliance in learning and not give up.

Accordingly, friendship also belongs to matters that make learning matter. It not only supports the process of dropping back into schooling, but also contributes to a shared belief in further education and future possibilities. Friendship mobilises support for learning, promotes deliberative communication between collaborative students and fosters a sense of belonging that does not undermine but instead advocates schooling. In this way, the performance gap between what students 
believe in, hope for and want to happen and what they actually end up with at first - school failure - closes. The involvements are shifting. Instead of being existential carriers of the constraints of friendships, where friendship supports escape from schooling, the students have become carriers of the possibilities of friendship - that is, friendship that mobilises and is part of the process of dropping back into schooling. We have thus moved away from the 'logic of interlocking friendship', which actively resisted schooling, to the logic of radial friendship, which actively mobilises schooling, school achievement and belief in further education, not only for oneself but also for others.

\section{Schooling}

When Bahar reflects on the meaning of Vista High in her life, her answer is assured and direct: 'It has built my life and if [Vista] hadn't existed, I wouldn't have made it as far as I have. Actually, I might have quit school altogether.' This lived experience, or even conclusion, is shared among the students who dropped back into schooling. Indeed, Vista High has made a great difference in their lives, because it has brought them all back to an approval of schooling, which neatly brings us back to the core aspect of the main question in this article: 'What are the matters that make learning matter at Vista High?' What has happened at this specific school? What has completely shifted the involvements with regard to schooling? Or, to frame it more analytically, what are the elementary forms that determine an enabling school opportunity structure that makes dropouts drop back into schooling? Let us hear what the students themselves have to say about this shifting involvement.

'When I shut the school door behind me in the afternoon,' Ziad declares, 'I immediately long to go back. Now that I know that school works for me, I have started to long for it. I go home, I go to the gym, I do my homework, and then I long to hand it in.' For Ziad, as for all the others, the most significant answer to our main question about matters that make learning matter concerns the teachers. 'Here at Vista,' he says, 'they'll do anything to help me, since they take care of me and they take responsibility for me. 'Every day they show spirit and fight for me and talk with me so that I will take the right path in life.' This means that he can 'really talk with the teachers' about 'everything' he feels he needs to talk about. In the end, however, the most important thing about schooling is proving that one is capable of learning. Ziad says, 'Now that I have proved that I am able to learn and that there is a chance, that's what really changed things in my life.' So he formulates his credo for life: 'The future starts in the classroom. That is just how it is.'

Ada came to Vista High without any passing grades at all. She has now passed eight classes, including one with distinction. Just like all the other interviewed students, Ada has regained a strong belief in her own capacity to learn. Thus succeeding in school is not only a matter of getting passing grades. As Trondman (2016b: 337) states, 'you must first and foremost learn so that you learn that you can learn'. This is exactly what Ada has discovered. It is no wonder she calls Vista High her second home: 'There the teachers stand by your side. They are like my friends, but only to a certain extent. They are also the teachers and we are the students. They are 'both serious and childish.' This means that the relationship between the teacher and students in the classroom is about focusing, cooperating, 
working hard and learning as well as being playful and having fun together. Thus there is a practice of recognition and solidarity going on at all possible interactive levels (see also Lund 2015b). The same applies to the relationships among students and newfound friends at Vista High, which means that, in Ada's own words, 'you can be yourself' and 'nobody laughs at you'. 'I would have loved to continue in this school for the rest of my life,' she concludes. 'This I can promise you, but it's not my whole life. You have to move on.'

By listening to Ada, Nazira, Ibra, Marsela, Ziad, Salma and Bahar, we can formulate five interrelated answers to our guiding question concerning the matters that make learning matter. We begin by letting Salma relate our answers in her own words. First, she feels that she can 'essentially talk about anything with the teachers'. Second, 'they show respect for different students, personalities, and needs'. Third, 'if you don't understand something you need to learn, they sit down with you and explain it until you understand'. Fourth, 'and every day in school I learn something new, a new word, new sentences and so on', which proves to Salma that she is able to learn. Finally, 'they never give up on you'. In other words, the teachers generate a lived school opportunity structure built on five deeply associated and strongly enabling elementary forms of schooling, which together explain why dropouts are dropping back into schooling at Vista High.

- a strong belief in and practices of deliberative communication - that is, a strong desire to get to know the needs and desires of students, showing students that the teachers want to be with them and do what they can to help them succeed in school

- a reliable practice of recognition and multifaceted incorporation - that is, the teachers respect, recognise and strive for inclusiveness regardless of differences, whether they be cultural, social or individual, which results in feelings of belonging and self-reliance among students

- a support of learning - that is, teachers who do what they can to turn teaching into learning, which shows students that the school and teachers can be believed in and trusted, because the teachers are doing what teachers are supposed to do

- a discovery of the ability to learn - that is, because of the teaching, the students come to realise that they actually can learn, which makes them want to learn more and feel good

- a strong sense of passion and perseverance among the students - that is, they experience teachers who want to be with them, who want to know them and learn from them, understand their needs and wants, who want them to succeed, who know how to help them and who do not give up on what they believe in and practise. This mobilises the same beliefs and practices among students, who in turn mobilise circuits of friends who share the same opportunity structure, and thus it increases the students' wellbeing. The students then make their families and friends happy, while at the same time expecting better opportunities.

Yet again, we can see that the performance gap is closing, because what the students believe in, hope for and want to happen - school achievement - is actually 
happening. Consequently, Nazira, Ibra, Marsela, Ziad, Salma, Ada and Bahar have all become existential carriers of the ability to learn. They have become school achievers by dropping back into belief in the practices of schooling. Instead of the logic of school failure, we now have the logic of school achievement. The students have been strongly and deeply moved by the elementary forms of enablement that make schooling a possibility and a lived resource in life.

\section{Gaps, logics and shifting involvements}

By listening to these students, we have learned that the lived possibilities of schooling can be awakened and the outcome of this can be rewarding for all three spheres examined here: family, friendship and schooling. We have learned about matters that make learning matter by revealing the shifting involvements that support dropouts to drop back into schooling. Indeed, all the gaps between family, friendship and schooling are closing and the logics of the temporality of the past are turning upside down. Accordingly, what the students are existential carriers of is also shifting. And although earlier life and structures of feeling cannot be undone, they can be redescribed in light of the outcomes of dropping back in and finding that one is capable of learning, as well as belonging to a happier family and a more socially productive circle of friends.

\section{Conclusion: Matters that make learning matter revisited}

The over-arching aim of this study has been to try to understand not only why young people who have a migration background and live under adverse circumstances may drop out of school, but also why they may drop back in. From our analytic viewpoint, these processes of dropping out and back in concern schooling - that is, as Oakeshott (2001: 69) puts it, 'when learning becomes learning by study, and not by chance, in conditions of direction and restraints'. The most profound answer to our question about matters that make learning matter concerns a school opportunity structure that makes it possible for dropouts to drop back into schooling. The very core of this structure for school achievement was theorised in terms of five deeply interdependent elementary forms: an environment permeated by the spirit of deliberative communication; recognition and multifaceted incorporation; learning support; discovery of the capability to learn; and passion and perseverance. No doubt, taking Nazira, Ibra, Marsela, Ziad, Salma, Ada and Bahar seriously, the truly decisive elementary form is the discovery of the capability of learning - that is, the profound lived experiences of those very moments where they discover that, thanks to schooling, they are actually able to understand and learn. This very discovery is the necessary but not sufficient understanding of why they are dropping back into schooling. This is so because the other four elementary forms are, in their own contributing way, as profound as the discovery of the capability of learning. This means that communication, recognition and incorporation, learning support, and passion and perseverance are those non-cognitive elements that make the discovery of the capability of learning possible.

Moreover, these interdependent elementary forms are inevitably dependent on teachers who are able to gain a strong relational capital (Trondman 2003) that is, teachers who are able to contribute to the closing of the performance gap regarding schooling by finding the precise and authentic lived relational forms of 
the elementary forms of schooling. Thus they have become teachers with such a legitimate authority that youth who have dropped out willingly start to engage in serious schooling - that is, they learn that they are capable of learning (see also Trondman: 2015; 2016b; Lund and Lund 2017; cf. Seymour 2012). In other words, the elementary forms that make learning matter need to be permeated with that very relational capital that makes those forms matter. This is exactly what has happened with the students from whom we have learned and who feature in this article. Furthermore, when the gap is closing with regard to schooling, it also profoundly contributes to the closing of gaps within families and among friends. The students, then, become existential carriers of all the possibilities that follow from all logics changing and all gaps closing, as one enabling structure of feeling, where schooling and hence a sense of belonging to the future become part of their self-understanding. Indeed, an enabling school opportunity structure for school achievement can, even in the face of adversity, make a big difference - just as in Nazira's, Ibra's, Marsela's, Ziad's, Salma's, Ada's and Bahar's lives, and possibly the lives of many others.

\section{Acknowledgements}

The authors would like to thank Nazira, Ibra, Marsela, Ziad, Salma, Ada and Bahar at Vista High for sharing their experiences and feelings connected to dropping out and dropping in processes. Many thanks as well to the anonymous reviewers for their valuable comments on earlier drafts of this article. We would especially like to thank Kathryn Seymour, guest editor, for the initiative of this special issue and for her constructive engagement along the way. The authors received financial support for the research from The Swedish Research Council (Dnr: 2009-6152).

\section{Endnotes}

1 In line with Duckworth (2016), we understand 'passion' as knowing, in a very deep way, what one believes in and wants - in our case, believing and wanting to succeed in school - while 'perseverance' refers to being 'resilient and hardworking' (2016: 8). Most often these two aspects of 'grit' work in tandem (2016: 57).

2 We use the terms 'dropout' or 'dropping out' in order to describe students who have not finished compulsory school with the required grades for the next educational step. We recognise that the term 'dropout' may have negative cultural connotations in some countries. The term that students in Sweden use themselves is 'IV-elev' [Introductory/Individual program student], referring to an institutionalised abbreviation of being a student who does not have the grades for entry to a national program in upper secondary school. This abbreviation is not portable to international contexts. The concepts 'dropout' or 'dropping out' are also used in academic journals such as the Journal of Adolescence and American Journal of Education. It is important to emphasise that dropouts are not what the students we write about are or were, but what they under certain circumstances came to be.

3 For Merton (1996a: 153), 'opportunity structure ... designates the scale and distribution of conditions that provide various probabilities for individuals and groups to achieve specific outcomes'.

4 We will illustrate how meaningful relationships support learning and development and contribute to school opportunity structures. Important themes for development such as motivation and school achievement, relationship building for positive peer, family and non-parental adult relations, supported by good leadership of teachers and an inclusive 
ethos in the framework of a school institution, permeate the article. We show how principles of practice developed for programs in one country, Australia (Seymour 2012), can display similarities in other countries and forums where adults work with children.

5 To Dilthey (1985: 223), 'lived experience' is a 'distinctive and characteristic mode in which reality is there-for-me ... It is there-for-me because I have a reflexive awareness of it, because I possess it immediately, as belonging to me in some sense.' See also Trondman et al. (2017).

6 It should also be added that dropout processes tend to begin at very early ages (Myklebust 2007).

7 Prior to 2011, receiving passing grades in Swedish (or Swedish as a second language), English and Maths was enough to qualify a student for upper secondary school. Since 2011, the college preparatory track requires passing an additional twelve subjects. The equivalent requirement for the vocational track is eight subjects.

8 That is being there by participating in organised activities, such as lessons, meetings, counselling, breakfasts and lunches, as well as all possible occasions of everyday school life, such as hanging around and chatting with people in hallways, recreation rooms and smoking areas, or on bus rides back and forth from school (Trondman et al. 2017).

9 This project was part of a larger project entitled 'An Educational Dilemma: Multicultural Incorporation and School Achievement' (2010-14). It was financed by the Swedish Research Council and led by Mats Trondman.

10 Ziad, Salma and Nazira were born in Sweden and have a Palestinian/Lebanese background. Ada, who has a Slovakian/Hungarian background, was also born in Sweden. Bahar, Ibra and Marsela were born in Kurdistan, Bosnia and Kosovo, respectively. With one exception, their parents held working-class jobs or were unemployed. Salma's family ran a small business in the field of car mechanics. None of the parents had high educational capital, either in Sweden or in their birth country. All the young participants shared experiences of growing up in territorially stigmatised neighbourhoods, where there is a constant risk of being framed as 'immigrants' with 'problems' and 'low status' who are probably 'disorderly' and lacking in the skills that make school achievement desirable and possible.

11 It may be added here that Swedish scholars in this field have emphasised the need for more research on the relationships between the areas of family, friendship, leisure and school achievement, especially among students with a migrant background (see Bouakaz 2007; Bunar 2010, 2015).

12 In Sweden, parents with a migrant background put more emphasis on education than parents without such a background, irrespectively of social background. Education is seem as being of great importance for their children, particularly when their families lack economic and educational resources (Trondman 2016a: 272-3).

13 See also Bouakaz (2007); Bunar (2015).

14 Thus it is not very difficult to analytically grasp the full-blown school-counter culture (Trondman 2015; Willis 1977).

15 Even if this article is focusing on schooling, it is also of importance to acknowledge that these students are also learners in a whole range of contexts and spaces. For example, they return to school also partly because they learned about its relevance in other contexts such as while being home with family.

\section{References}

Ambrose A. 2016. Att navigera på en skolmarknad - en studie av valfribetens geografi $i$ tre urbana skolor. Stockholm: Barn och ungdomsvetenskapliga institutionen, Stockholms universitet. 
Bouakaz L. 2007. Parental involvement in school: What hinders and what promotes parental involvement in an urban school, Malmö: Malmö University College Studies in Educational Sciences.

Bunar N. 2001. Skolan mitt i förorten. Stockholm/Stehag: Symposion.

— 2009. När marknaden kom till förorten: valfrihet, konkurrens och symboliskt kapital $i$ mångkulturella skolor. Lund: Studentlitteratur.

— 2010. Nyanlända och lärande. Stockholm: Vetenskapsrådet.

— 2015. Nyanlända och lärande — mottagande och inkludering. Stockholm: Natur och Kultur.

Bunar N. and Sernhede O. (eds) 2013. Skolan och ojämlikhetens urbana geografi. Om skolan, staden och valfribeten. Göteborg: Daidalos.

Cederberg M. 2012. 'Gymnasieskola — inte en skola för alla?’ Rapport från Malmö stad.

Cohen D.K. 2011. Teaching and its predicament, Chicago, IL: University of Chicago Press.

Dilthey W. 1985. Poetry and experiences: Selected works volume V. Princeton, NJ: Princeton University Press.

Duckworth A. 2016. Grit: The power of passion and perseverance. London: Vermilion.

Geertz C. 1999. A life of learning. Charles Homer Haskins Lecture for 1999. Washington, DC: American Council of Learned Societies.

Kallstenius J. 2010. De mångkulturella innerstadsskolorna: om skolval, segregation och utbildningsstrategier $i$ Stockholm. Stockholm: Stockholms universitet.

Lund. A. 2015a. 'From pregnancy out of place to pregnancy in place: Across, within and between landscapes of meaning', Ethnography 18(1): 76-87.

- 2015b. 'At a close distance: Dropouts, teachers, and joking relationships', American Journal of Cultural Sociology 3: 280-308.

— 2016. 'När allt annat misslyckats', in A. Lund and S. Lund (eds), Skolframgång i det mångkulturella sambället. Lund: Studentlitteratur.

Lund A. and Lund S. 2017. " "Eftersom vi skrattar åt det så fastnar det batter": Humor och relationell lärarauktoritet', in M. Trondman and M. Lennartsson (eds), Auktoritet. Göteborg: Daidalos.

Lundahl L., Erixon-Arreman I., Holm A. and Lundström U. 2014. Gymnasiet som marknad. Umeå: Boréa.

Merton R.K. 1996a. 'Opportunity structure', in R.K. Merton, On social structure and science, Chicago: Chicago University Press.

— 1996b. 'The self-fulfilling prophecy', in R.K. Merton, On social structure and science, Chicago: Chicago University Press.

Myklebust J. 2007. 'Diverging paths in upper secondary education: Competence attainment among students with special educational needs', Journal of Inclusive Education, 11(2): 215-31.

National Agency for Education 2008. Studieresultat i gymnasieskolan - en statistisk beskrivning av ofullständiga gymnasiestudier. Stockholm: Fritzes.

- 2014a. Introduktionsprogram. Stockholm: Fritzes.

— 2014b. 'Högre betyg men fler är obehöriga till gymnasiet'. Press communiqué, Skolverket, http://www.skolverket.se/press/pressmeddelanden/2014/ hogre-betyg-men-fler-ar-obehoriga-till-gymnasiet-1.224026. 
Norberg H. 2003. 'Skolmisslyckanden - hur gick det sen?', http:// www.regeringen.se/content/1/c4/37//66/6076845a.pdf.

Oakeshott M. 2001. The voice of liberal learning. New Haven, CT: Yale University Press.

Seymour K. 2012. Good practice principles for youth development organisations. 2nd ed. Brisbane: Key Centre for Ethics, Law, Justice and Governance, Griffith University.

Trondman M. 2003. Kloka möten. Om den praktiska konsten att bemöta barn och ungdomar. Lund: Studentlitteratur.

2011. 'To locate in the tenor of their setting the sources of their spell: Clifford Geertz and the "strong" program in cultural sociology', in J.C. Alexander, P. Smith and M. Norton (eds), Interpreting Clifford Geertz: Cultural investigation in the social sciences. New York: Palgrave Macmillan.

— 2015. 'Taking normative sense seriously', Ethnography 18(1): 10-23.

2016a. Skolframgångens elementära former: variationer i möjligheter och begränsningar, in A. Lund and S. Lund (eds), Skolframgång $i$ det mångkulturella sambället. Lund: Studentlitteratur.

_ 2016b. 'Till förståelsen av det mångkulturellas betydelse för skolframgång', in A. Lund and S. Lund (eds), Skolframgång $i$ det mångkulturella sambället. Lund: Studentlitteratur.

Trondman M., Taha R. and Bouakaz L. 2014. 'Deras, vårt och jag: om den kulturella tillhörighetens, hälsans och skolframgångens meningslandskap i det mångkulturella samhället', in O. Sernhede and I. Tallberg Broman (eds), Segregation, utbildning och ovanliga läroprocesser. Malmö: Liber.

Trondman M., Taha R. and Lund A. 2012. 'For Aïsha: On identity as potentiality', Identities: Global Studies in Culture and Power 19(4): 533-43.

Trondman M., Willis P. and Lund A. 2017. 'Lived forms of schooling: Bringing the elementary forms of ethnography to the science of education', in D. Beach, C. Bagely and S. Marques da Silva (eds), Handbook of ethnography of education, London: Wiley.

Willis P. 1977. Learning to labour. How working class kids get working class jobs. Aldershot: Ashgate. 